\title{
Enabling the Participation in Public Organization Cost Reduction Policy Implementation through Civil Servants’ Affective Commitment
}

\author{
Mohamad Hisyam Selamat \\ Faculty of Business, Accounting and Management, SEGi University, Petaling Jaya, Malaysia \\ mohdhisyam@segi.edu.my \\ Rafeah Mat Saad \\ School of Accountancy, Universiti Utara Malaysia, Sintok, Malaysia \\ rafeah@uum.edu.my \\ Rusdi@ Indra Zuhdi Murat \\ School of Quantitative Sciences, Universiti Utara Malaysia, Sintok, Malaysia \\ m.rusdi@uum.edu.my
}

Foo Kok Soon

Singapore Polytechnic Business School, Singapore

johnfoo57@outlook.com

Received: July 1, 2016 Accepted: July 8, 2016 Published: January 5, 2018

doi:10.5296/jpmr.v4i1.9683 URL: http://dx.doi.org/10.5296/jpmr.v4i1.9683

\begin{abstract}
The present study is designed to propose values for developing civil servants' affective commitment to support public organization cost reduction policy implementation. The proposed values are faith, sincerity, trusting belief, trusting intention and emotional trust. The researchers have applied cross-sectional survey research to validate the framework. It is found that faith, sincerity and emotional trust influenced the development of civil servants'
\end{abstract}


affective commitment to support the implementation of public organization cost reduction policy significantly. The practical implications are the discovery of theoretical, personal, and workplace practical best practices for the establishment of strategies to reduce operational costs in the public organizations.

Keywords: Faith, Sincerity, Trusting Belief, Trusting Intention, Emotional Trust, Knowledge Sharing, Public Organization

\section{Introduction}

One of the measurements in determining fiscal strength of a country is deficit rate (Blanchard, 2011; Omar Othman et al., 2007). They stated that there are two ways of reducing budget deficit which are increasing revenue and reducing expenditure. However, the focus of this research is on reducing expenditure. As a big chunk of tax revenues of any country including Malaysia is contributed by corporate tax, the area of increasing revenue is quite complicated as it is depending on global economy, which is always fluctuating. Cost reduction is normally an internal matter of government agencies or departments, which can be monitored and controlled by the director general. Thus the study on this phenomenon is much more feasible and practical.

Cost reduction field of study is closely related to organizational effectiveness and efficiency. However, most of the studies on public sector relate effectiveness and efficiency to issues such as quality service, public satisfaction, managerial accountability and public stewardship. In other words, people expect high quality of service and good living environment (high income and low cost of living) from the government. This poses a big challenge to the government as to whether they want to be a populace government, which leads to worst fiscal deficit, or growth-friendly government. To sustain prosperity, during fiscal deficit period, this research argues that the government should reduce public expenditure without compromising on the concepts of people caring and steady economic growth. This could also lead to the perception that the current government is working with full integrity. Nevertheless, civil servants must support the implementation of cost reduction policy to ensure its success.

There are three components of attitudes, namely, cognitive, affective or behavioural responses (Min \& Lee, 2009; Simon \& Peppas, 2004). Thus it could be said that one of the elements that influences civil servants' acceptance on public organization cost reduction policy is their affective commitment towards that policy. Affective commitment refers to the emotional or psychological connection of an individual to identify and participate in the organization (Meyer \& Allen, 1991). The purpose of this research is to examine values that can develop civil servants' emotional and psychological connection to public organization cost reduction policy so that they are more willing to accept its implementation.

To assist in the process of developing civil servants' affective commitment towards cost reduction policy, this research proposes the elements of faith, sincerity, trusting belief, trusting intention and emotional trust. All these values are embedded in the conceptual framework. In other words, the objective of this research is to examine factors that can 
develop civil servants' affective commitment to support the implementation of cost reduction policy in the workplace.

The paper is organized as follows. Next section presents a theoretical justification for every element in the conceptual framework. Section 3 discusses research approach adopted to validate the proposed factors. Finally, a conclusion is presented in the concluding section.

\section{Theoretical Overview}

For the theoretical understanding of public organization cost reduction we posit that public organization cost reduction is based on the concept of individual affective commitment. In the following sections a discussion of public organization cost reduction and affective commitment is offered.

\subsection{Public Sector Financial Management}

The most important activity in public sector financial management is budgeting. There are three types of government budget, namely, deficit budget, surplus budget and balanced budget. Amongst the three types of government budget, deficit budget is the one that is usually creating negative perception amongst people and business community (Alessi, 2012; Blanchard, 2011). This is because it shows government incapability in controlling expenditures and increasing revenues. The failure to increase revenues is also related to the failure to create business activities through public projects such as infrastructure, highway, hospital, school and others. Thus managing deficit rate for the sake of economic growth is critical to every country including Malaysia.

Due to negative impact of high deficit rate on the financial system and fiscal strength, a country that has high deficit rate is usually given low rating by the credit rating agencies such as Standard \& Poor, Moody's, and Fitch Group (Alessi, 2012). The country that get poor rating will be imposed higher interest rate by the international financial institutions including companies incorporated in that country. This will affect badly domestic direct investment in the country (Blanchard, 2011). Foreign direct investment will be also badly affected because foreign investors are reluctant to invest in a country that is not financially and politically stable (Blanchard, 2011). Low investment will reduce economic growth and in turn increase unemployment rate in the country (Blanchard, 2011). This is the scenario that every government in the world, including Malaysia, is trying to avoid. Thus obtaining good ratings through balanced budget or lower deficit rate is a must for every country.

There are two ways of reducing budget deficit which are increasing revenue and reducing expenditure (Blanchard, 2011; Omar Othman et al., 2007). However, the focus of this research is on reducing expenditure. As $80 \%$ of Malaysian tax revenues contributed by corporate tax, the area of increasing revenue is quite complicated as it is depending on global economy, which is always fluctuating. Cost reduction is normally an internal matter of ministries, departments and agencies, which can be monitored and controlled by the government (Omar Othman et al., 2007). Thus the study on this phenomenon is much more feasible and practical and in tandem with the aspiration of the government. 


\subsection{Public Organization Cost Reduction and Affective Commitment}

The reduction of government expenditure is always looked at the organizational perspective. In this case, the ministries, departments and agencies have to cut several non-critical expenses and postpone non-critical projects. This study, however, will look at the individual perspective because it is quite difficult to get access data on public expenditure from the organizational perspective.

Based on the above discussion, civil servants must be emotionally receptive towards cost reduction policy to ensure the success of its implementation in the workplace. As cost reduction policy is considered as an austerity plan, civil servants must have a high level of emotional and psychological connection towards it before they could participate in the process of identifying the strategies to implement low-cost yet high-impact public services. Trivializing this issue could lead to ineffective and inefficient implementation of cost reduction policy. In turn, the increase in public organization operational costs is inevitable. To face such phenomenon, this research argues that civil servants need to be equipped with positive value of faith, sincerity, trusting belief, trusting intention and emotional trust. Civil servants who are not embedded with these values tend to be reluctant to support the implementation of cost reduction policy in the workplace.

\subsection{Developing Civil Servants’ Affective Commitment}

As stated above, affective commitment refers to the emotional or psychological connection of an individual to identify and participate in the organization (Meyer \& Allen, 1991). Affective commitment construct is developed based on Meyer and Allen's (1991) organizational commitment model. The focus of this research is on what values that can develop civil servants' self-commitment (individual commitment) and not what public organization should do to increase civil servants' commitment in public organization cost reduction (organizational commitment). In other words, this research extends the use of Meyer and Allen's (1991) model. This research proposes five values that could develop civil servants' affective commitment to share knowledge, namely, faith, sincerity, trusting belief, trusting intention and emotional trust.

\subsubsection{Faith}

Faith is a great trust or confidence in something or someone (Cambridge International Dictionary of English, 1995). Its position is much higher than trust or confidence. From the perspective of this research, having faith in cost reduction policy and its role in sustaining economic growth enables civil servants to have strong emotional or psychological connection to it. In turn, motivates them to share ideas and opinions on what is the best strategy to reduce operational costs in the workplace.

Pedler, Burgoyne and Boydell (1994), Butcher, Harvey and Atkinson (1997) and Harvey and Butcher (1998) found that there is a significant relationship between faith in organization and organizational performance. On the other hand, Selamat and Choudrie (2007) and Abdul Wahab, Selamat and Saad (2013) found a significant relationship between faith in organization and the willingness to externalize and share knowledge and skills within the 
organization. Haldin-Herrgard (2000) further supported this axiom by saying that lack of faith prevents staff members from externalizing and sharing their tacit knowledge in the workplace. Based on the above discussion, it is argued that there is a potential relationship between faith and civil servants affective commitment to implement cost reduction policy in the workplace. Thus the following hypothesis is developed:

H1: There is a relationship between faith and affective commitment to implement cost reduction policy amongst civil servants

\subsubsection{Sincerity}

Sincerity is the most important value that should be instilled in the workplace including public organizations. Every civil servant must have a feeling that he or she works for the sake of the people and for fulfilling his or her responsibility to the country. The important role of sincerity in developing effective individuals has been stressed by Schroder (1989). This is further supported by Selamat et al. (2015), Selamat and Choudrie (2007), Abdullah and Selamat (2007) and Abdul Wahab, Selamat and Saad (2012). They obtained an effective role of sincerity in motivating staff members to participate in learning environment. The main reason why an organization recruits people is to assist management in the maximizing of its profits. Thus every recruited staff has to bear in his or her mind in the workplace that "we must perform organizational tasks sincerely.” The value of sincerity also gives staff members a strength to ignore any negative sentiment to the management, that is created through gossip and slander (Schroder, 1989; Selamat \& Choudrie, 2007). This represents their positive emotional and psychological connection to the organization. Being equipped with this feeling makes them more supportive when are asked to give ideas on how to reduce office expenditure - involvement in cost reduction policy implementation. Thus the following hypothesis is proposed:

H2: There is a relationship between sincerity and affective commitment to implement cost reduction policy amongst civil servants

\subsubsection{Trusting Belief}

According to Mayer et al. (1995), trusting belief consists of three attributes: (1) competence belief that means staff members have confidence that the organization has the necessary skills to perform the job; (2) benevolence belief that reflects staff members' confidence that the organization has a positive orientation toward them and not only consider their profit goals; and (3) integrity belief that reflects staff members' confidence that the organization following a set of moral principles or professional standards that guide user-organization relationships. These trusting beliefs are related, yet distinct.

Beatty et al. (2011), McKnight et al. (2002) and McKnight et al. (1998) examined the above three attributes of trusting belief from the perspective of e-commerce transaction and found significant relationships between them. Thus it is argued that if civil servants have beliefs that reducing public sector expenditure is critical in reducing national deficit rate and in turn attaining good international ratings they will be more receptive towards cost reduction policy. This represents their positive emotional and psychological connection to the organization. 
Being equipped with this feeling makes them more supportive when are asked to give ideas on how to reduce office expenditure - involvement in cost reduction policy implementation. Thus the following research hypothesis is proposed:

H3: There is a relationship between trusting belief and affective commitment to implement cost reduction policy amongst civil servants

\subsubsection{Trusting Intention}

Trusting intention is defined as the intention to engage with the organizations that staff members feel secure with (McKnight et al., 2002). It can also be described as "to what extent staff members are willing to involve in risky situation” (Kim et al., 2004, p. 105). Schlosser et al. (2006) uncovered that online buyers are willing to provide their personal information such as credit card number, address and contact number (which could ruin their life) to the firms if they trust them. To incorporate e-commerce scenario into this study, civil servants are expected to be more receptive towards cost reduction policy if they trust the reasons why the government need to implement such policy. This represents their positive emotional and psychological connection to the organization. Being equipped with this feeling makes them more supportive when are asked to give ideas on how to reduce office expenditure involvement in cost reduction policy implementation. Thus this study proposes the following hypothesis:

H4: There is a relationship between trusting intention and affective commitment to implement cost reduction policy amongst civil servants

\subsubsection{Emotional Trust}

Emotional trust refers to feeling toward the behaviour of relying on the other side (trustees) (Komiak \& Benbasat, 2006). Xie and Peng (2011) stated that emotional trust reinforces relationship between organizations and staff members. Beatty et al. (2011) and Min and Lee (2009) stated that emotional trust and cognitive trust complement each other perfectly in influencing an individual's decision on whether to trust or not the other party. In e-commerce transaction, the buyers tend to emotionally response to product or seller which making the decision becomes less cognitively dominated (Komiak \& Benbasat, 2006). Thus it could be said that if civil servants have an emotion that Malaysia must achieve low deficit rate in order to obtain good ratings and in turn positive economic growth, they will become more receptive towards cost reduction policy. This emotion in turn motivates them to participate actively in the brainstorming session that aims to determine the best strategy to reduce office expenditure - involvement in cost reduction policy implementation. All these scenarios lead to the following hypothesis:

H5: There is a relationship between emotional trust and affective commitment to implement cost reduction policy amongst civil servants

\section{Research Methodology}

Data of this study were gathered through a survey approach. Survey is considered to be the favoured tool for data collection amongst quantitative researchers (Fowler, 2009). In addition, 


\section{Macrothink}

it is one of the most common data collection methods for examining the participation in cost reduction commitment and knowledge sharing commitment (Selamat et al., 2015; Jain \& Jeppesen, 2013; Amayah, 2013). Survey research suits the unit of analysis of this study, which are civil servants in the Malaysian public organizations. Dwivedi (2005) suggested that when the unit of analysis is individual rather than organization, survey approach is more preferable than other approaches such as case study. This study utilized stratified random sampling as a sampling technique. Stratified random sampling, as its name implies, involves a process of stratification or segregation, followed by random selection of subjects from each stratum (ministries) (Sekaran, 2003; Fowler, 2009; Babin \& Griffin, 2010). A total of 400 civil servants in federal government ministries across Malaysia were randomly selected. The questionnaires were distributed by liaison officers (most of them are auditors of the Auditor's General Department). They were selected because they have the authority to communicate with the respondents. Multiple regression analysis was used to test the relationship between independent variables and dependent variable.

\section{Research Findings}

Out of 400 distributed questionnaires, 130 were returned. This resulted in a response rate of $32.5 \%$. As suggested by Sekaran (2003), a response rate of $30 \%$ is considered adequate for mail survey research. Based on this suggestion, the response rate of this study (32.5\%) was above the recommended rate. In turn, the findings of this research can be generalized to the population.

\subsection{Profile of Respondents}

Table 1. Background of the Respondents $(\mathrm{N}=130)$

\begin{tabular}{lll}
\hline Gender & Frequency & Percentage \\
Male & 56 & \\
Female & 74 & 53.1 \\
\hline Age (years) & & \\
$21-30$ & 5 & 3.8 \\
$31-40$ & 59 & 45.4 \\
$41-50$ & 40 & 30.8 \\
$51-60$ & 26 & 20.0 \\
$>60$ & - & - \\
\hline Length of Service & & \\
$<5$ & 30 & 23.1 \\
$<10$ & 40 & 30.8 \\
$<15$ & 16 & 12.3 \\
$<20$ & 20 & 15.4 \\
$>21$ & 24 & 18.5 \\
\hline
\end{tabular}


The frequency and percentage of each demographic profile are illustrated in Table 1 . The reported demographic profiles include gender, age and number of years working in the current university.

In this research, gender distribution was slightly higher for female. Out of 130 respondents, 56 (43.1\%) respondents are male and 74 (56.9\%) respondents are female. The largest group of respondents $(\mathrm{N}=59,45.4 \%)$ reported that they were in the "31-40" age group. The second largest group consisted of respondents with age " $41-50$ ” ( $\mathrm{N}=40,30.8 \%)$, third largest group consisted of respondents with age "51-60" ( $\mathrm{N}=26,20.0 \%)$ and fourth largest group consisted of respondents with age "21-30" ( $\mathrm{N}=5,3.8 \%)$. There was no respondent in "Over 60" age group.

The largest group of respondents $(\mathrm{N}=40,30.8 \%)$ indicated that they have worked at the current university " 10 years or less". The second largest group of respondents $(\mathrm{N}=30,23.1 \%)$ reported that they have worked at the current organization " 5 years or less). This is followed by “over 21 years” category ( $\mathrm{N}=24,18.5 \%)$.

\subsection{Reliability Analysis}

To test the reliability of the research instrument, as suggested by Sekaran (2003), this study utilized internal consistency method which is measured by Cronbach's alpha. The coefficient for the Cronbach's alpha is expressed between 0 and 1.00. The results of the Cronbach's alpha values of the variables are as illustrated in Table 2.

Table 2. Reliability Coefficients for Variables ( $\mathrm{N}=130)$

\begin{tabular}{lcc}
\hline Variable & N of Item & Cronbach Alpha \\
\hline Faith & 6 & 0.858 \\
Sincerity & 6 & 0.937 \\
Trusting belief & 20 & 0.918 \\
Trusting intention & 9 & 0.838 \\
Emotional trust & 8 & 0.668 \\
Affective commitment to implement cost reduction policy & 6 & 0.895 \\
\hline
\end{tabular}

As shown in Table 2, the Cronbach's alpha values for variables varied between 0.668 (emotional trust) and 0.937 (sincerity). Two variables possessed Cronbach's alpha values above 0.90 (sincerity and trusting belief), three between 0.80 and 0.90 (faith, trusting intention and affective commitment to implement cost reduction policy) and one below than 0.70 (emotional trust). In other words, none of the study variables demonstrated below the minimum reliability level of 0.60 (Hair, Black, Babin, Anderson, \& Tatham, 2006). Thus the internal consistency of the measures used in this study was considered acceptable (Churchill, 1979; Sekaran, 2003). 


\subsection{Multiple Regression Analysis}

Date refinement was undertaken prior to multiple regression analysis. It was divided into data screening and data testing, which aim to fulfill the multivariate assumptions (Hair et al., 2006). Data screening consists of three tests which are missing data, response bias and outliers identification. On the other hand, data testing consists of linearity, normality, homoscedasticity and multicollinearity tests. The criteria for all these tests were met in this study.

To test this research hypotheses multiple regression analysis was utilized and its findings are illustrated in Tables 3, 4 and 5. As illustrated in Table 3, the value of adjusted R square is 0.597. This shows that all independent variables (faith, means, contemplation, sincerity, goal obsession and attitude towards university) explain $59.7 \%$ variance in the commitment to encourage students to share knowledge.

Table 3. Effect of Affective Commitment on Cost Reduction Commitment

\begin{tabular}{llll}
\hline & B & t & Sig. \\
\hline Faith & .501 & 6.536 & .000 \\
Sincerity & .282 & 3.428 & .001 \\
Trusting Belief & .156 & 1.292 & .199 \\
Trusting Intention & .211 & 1.377 & .171 \\
Emotional Trust & .320 & 3.224 & .002 \\
$\mathrm{R}^{2}$ & 0.619 & & \\
F & 40.267 & & \\
Sig. & 0.000 & & \\
\hline
\end{tabular}

Only three variables were found to have significant effect on the commitment to encourage students to share knowledge. They were faith $(B=0.501, t=6.536, p<0.01)$, sincerity $(B=0.282$, $\mathrm{t}=3.428, \mathrm{p}<0.01)$ and emotional trust $(\mathrm{B}=0.320, \mathrm{t}=3.224, \mathrm{p}<0.01)$. Thus $\mathrm{H} 1, \mathrm{H} 2$ and $\mathrm{H} 5$ were accepted.

\subsection{Discussion}

This study found that faith was positively and significantly influenced civil servants' affective commitment to participate in the implementation of cost reduction policy in the workplace. This finding is consistent with the previous studies such as Selamat et al. (2015), Jain and Jeppesen (2013) and Amayah (2013). From this result it could be said that civil servants that have low faith or do not believe in cost reduction policy will not give full commitment to its implementation. This is because reducing expenditure requires prudent planning and two-way communication between management and civil servants and also amongst civil servants themselves. Thus civil servants must be embedded with the belief that 
cost reduction policy is capable of improving national fiscal strength and in turn international ratings. This belief in turn will motivate them to actively participate in the implementation of cost reduction policy in the workplace.

This study also found that sincerity was positively and significantly influenced civil servants' affective commitment to involve in the implementation of cost reduction policy in the workplace. This finding is consistent with the previous studies such as Selamat and Choudrie (2007), Abdullah and Selamat (2007) and Abdul Wahab et al. (2012). In other words, sincerity was perceived by civil servants as the influencing factor to participate or not to participate in cost reduction policy implementation. The probable explanation could be the norm that sincerity is the most important value in every human endeavour and cost reduction is not exceptional. This is because, based on the norm of reciprocity, when public organization offers job and salary to sincere civil servants, they may feel obligated to reciprocate and become more committed to organizational success.

This study also found that emotional trust was positively and significantly influenced civil servants' affective commitment to participate in the implementation of cost reduction policy in the workplace. This finding is consistent with the previous studies such as Selamat et al. (2015), Jain and Jeppesen (2013) and Amayah (2013). Thus having trust that the government need to implement cost reduction policy to protect economic growth is a prerequisite before civil servants could participate in the implementation of cost reduction policy. The probable reason behind this scenario is that cost reduction usually involves cut in allowance, bonus, entertainment and training, which are considered as sensitive issue by civil servants. Thus adequate explanation on the cost reduction policy needs to be conducted by the management.

Surprisingly, this study found that trusting belief and trusting intention were not positively and significantly influenced civil servants' affective commitment to participate in the implementation of cost reduction policy. Implicit in this finding is that an emotion plays more role in influencing civil servants' actions in the workplace than cognitive role (trusting belief and trusting intention). This scenario occurs due to the understanding (cognitive) that public sector is the biggest sector in Malaysia and it has a very comprehensive and sophisticated system in managing the whole nation. Thus the one that really influences daily activities in the workplace is emotion. This might explain why emotional trust has significant relationship with affective commitment to participate in cost reduction policy implementation and not cognitive component (trusting belief and trusting intention). In short, to develop civil servants' affective commitment to participate in the implementation of cost reduction policy the elements of faith, sincerity and emotional trust need to be given more attention by the public organization.

\section{Conclusion}

The objective of this study was to determine whether individual affective commitment (faith, sincerity, trusting belief, trusting intention and emotional trust) develop civil servants' commitment to participate in the implementation of cost reduction policy. From the findings, the proposed conceptual framework was substantially validated. The findings showed that the 
effect of faith, sincerity and emotional trust on the commitment to participate in the implementation of cost reduction policy in the workplace was significant.

Although this study have contributed to public financial management area, but several limitations have to be considered. First, the context of this study is limited to civil servants. For future research it is suggested that a comparison is made between civil servants and practitioners. Second, this research conceptual framework was tested and examined from the Malaysian perspective. Thus obtaining feedback from the public sector in other countries is necessary. Third, this research adopted cross-sectional survey for data collection. To gain broad view on the issues related to public organization cost reduction and knowledge sharing, a longitudinal study is advised. Last but not least, unit of analysis of this study was an individual whereby civil servants were selected as the respondents. To gain more variance in the analysis, obtaining feedback from all individuals working in the public sector is strongly recommended.

\section{References}

Abdul Wahab, M. S., Selamat, M. H., \& Saad, R. A. (2012). Work environment inhibitors to informal workplace learning activities amongst accountants: A Malaysian case study. Paper presented at the first UUMCOB Qualitative Research Conference, Kuala Lumpur (4-7 November 2012).

Abdul Wahab, M. S., Selamat, M. H., \& Saad, R. A. J. (2013). The importance of continuing professional education activities amongst Malaysian accountants in public accounting firms. Paper presented at the fourteenth Asian Academic Accounting Association, Penang.

Abdullah, A., \& Selamat, M. H. (2007). Preparing individuals for establishing learning-based management accounting and control system. Paper presented at the Accounting Studies International Conference, Kuala Lumpur (30-31 October 2007).

Alessi, C. (2012). The credit rating controversy, campaign 2012. Council on Foreign Relations. Retrieved 29 May 2013.

Amayah, A. T. (2013). Determinants of knowledge sharing in a public sector organization. Journal of Knowledge Management, 17(3), 454-471.

Babin, Z., \& Griffin, C. (2010). Business research method (8th ed.). Ohio: South-Western/Cengage Learning.

Beatty, P., Reay, I., Dick, S., \& Miller, J. (2011). Consumer trust in e-commerce web sites. ACM Computing Surveys, 43(3), 1-46. doi:10.1145/1922649.1922651

Blanchard, O. (2011). Macroeconomics, 5th Edition. New York: Pearson.

Butcher, D., Harvey, P., \& Atkinson, S. (1997). Developing business through developing individuals. Research Paper, Cranfield School of Management, Cranfield University.

Cambridge International Dictionary of English (1995). Bath, UK: Bath Press. 
Churchill, G. A. (1979). A paradigm for developing better measures of marketing constructs. Journal of Marketing Research, 16(1), 64-73.

Dwivedi, Y. K. (2005). Adoption, usage and impact of broadband: UK households (Unpublished doctoral dissertation). Brunel University, UK.

Fowler, F. J. Jr. (2009). Survey research method. London: Sage Publications.

Hair, J. F., Black, W. C., Babin, B. J., Anderson, R. E., \& Tatham, R. L. (2006). Multivariate data analysis (6th ed.). New Jersey: Pearson International Edition.

Haldin-Herrgard, T. (2000). Difficulties in diffusion of tacit knowledge in organisations. Journal of Intellectual Capital, 1(4), 357-365.

Harvey, P., \& Butcher, D. (1998). Those who make a difference: developing businesses through developing individuals. Industrial and Commercial Training, 30(1), 12-15.

Jain, A. K., \& Jeppesen, H. J. (2013). Knowledge management practices in a public sector organisation: the role of leaders' cognitive styles. Journal of Knowledge Management, 17(3), 347-362.

Kim, P. H., Ferrin, D. L., Cooper, C. D., \& Dirks, K. (2004). Removing the shadow of suspicion: The effects of apology versus denial for repairing competence- versus integrity-based trust violations. Journal of Applied Psychology, 89(1), 104-118.

Komiak, S. Y. X., \& Benbasat, I. (2006). The effects of personaization and familiarity on trust and adotion of recommendation agents. MIS Quarterly, 30(4), 941-960.

McKnight, D. H., Choudhury, V., \& Kacmar, C. (2002). Developing and validating trust measures for e-commerce: An integrative typology. Information Systems Research, 13(3), 334-359. doi:10.1287/isre.13.3.334.81

McKnight, D. H., Cummings, L. L., \& Chervany, N. L. (1998). Initial trust formation in new organizational relationships. The Academy of Management Journal, 23(3), 473-490.

Mayer, R. C., Davis, J. H., \& Schoorman, F. D. (1995). An integrative model of organizational trust. The Academy of Management Review, 20(3), 709-734.

Meyer, J. P., \& Allen, N. J. (1991). A three-component conceptualization of organizational commitment. Human Resource Management Review, 1(61). doi:10.1016/1053-4822(91)90011-Z.

Min, J. Y., \& Lee, H. (2009). Getting emotional with the system that mirrors you: Cognitive and affective attitudes towards identity-reflecting information systems. In PACIS. Hyderabad, India. Retrieved from http://aisel.aisnet.org/pacis2009/50

Omar Othman, Mohamad Sharofi Ismail, Syed Soffiaan Syed Ismail and Siti Zabedah Saidn (2007). Public sector accounting in Malaysia. Kuala Lumpur: Thomson Learning.

Pedler, M., Burgoyne, J., \& Boydell, T. (1994). A manager's guide to self-development. London: McGraw-Hill. 


\section{Macrothink}

Journal of Public Management Research

ISSN 2377-3294

2018, Vol. 4, No. 1

Schlosser, A. E., White, T. B., \& Lloyd, S. M. (2006). Converting web site visitors into buyers: How web site investment increases consumer trusting beliefs and online purchase intentions. American Marketing Association, 70(April), 133-148.

Schroder, H. (1989). Managerial competence: The key to excellence. New York: Kendall/Hunt Publishing.

Sekaran, U. (2003). Research method for business: A skill building approach (4th ed.). Danvers, MA: John Wiley \& Sons.

Selamat, M. H., \& Choudrie, J. (2007). Using meta-abilities and tacit knowledge for developing learning based systems: A case study approach. The Learning Organization, 14(4), 321-344.

Selamat, M. H., Selladurai, S., \& Abdul Halim, H. M. (2015). The influence of task accomplishment and attitude on active teaching in Malaysian universities. European Journal of Business and Social Science, 4(1), 35-48.

Simon, S. J., \& Peppas, S. C. (2004). An examination of media richness theory in product web site design: An empirical study. Info, 6(4), 270-281.

Xie, Y., \& Peng, S. (2011). How do corporate associations influence customer relationship strength? The effects of different types of trust. Journal of Strategic Marketing, 19(5), 443-454. doi:10.1080/0965254X.2011.565882

\section{Copyright Disclaimer}

Copyright for this article is retained by the author(s), with first publication rights granted to the journal.

This is an open-access article distributed under the terms and conditions of the Creative Commons Attribution license (http://creativecommons.org/licenses/by/3.0/). 